Pathophysiology

of Haemostasis

and Thrombosis
Pathophysiol Haemost Thromb 2002;32:174-179

DOI: $10.1159 / 000070423$
Received: May 3, 2002

Accepted after revision: October 30, 2002

\title{
Effect of Phenprocoumon on Monitoring of Lepirudin, Argatroban, Melagatran and Unfractionated Heparin with the PiCT Method
}

\author{
T. Fenyvesi I. Jörg J. Harenberg \\ Fourth Medical Department, University Hospital, Mannheim, Germany
}

\section{Key Words}

Prothrombinase-induced clotting time $\cdot$ Thrombin inhibitors · Phenprocoumon · Additive effects

\begin{abstract}
Prothrombinase-induced clotting time (PiCT) is a clotting-time test for heparins and direct thrombin inhibitors to reduce drawbacks of aPTT. Effects of the direct thrombin inhibitors lepirudin, argatroban, melagatran and of unfractionated heparin (UFH) were investigated in normal and oral anticoagulant plasma samples. Lepirudin showed potentiating interferences with phenprocoumon effects. Melagatran, argatroban and UFH delivered distinct linear additive effects in both plasma sample groups. PiCT ratio reduces differences between both groups with UFH, and argatroban inhibitor-receptorbinding mode plays a role in interaction patterns.
\end{abstract}

Copyright $@ 2002$ S. Karger AG, Basel

\section{Introduction}

In clinical use, heparins and direct thrombin inhibitors are mostly monitored by aPTT [1,2]. Limitations of aPTT methods include non-linear dose-effect relationships with a plateau effect, variability between different testing instruments, reagents and different lots of the same reagent [3]. These limitations are enhanced when patients receive an overlapping therapy consisting of an oral anticoagulant in combination with heparin or a direct thrombin inhibitor.

Recently, a snake venom-based testing method, the ecarin clotting time (ECT), has been developed to obtain linear dose-response relationships with direct thrombin inhibitors. This method is therefore more accurate in monitoring hirudin and argatroban than aPTT [2, 4]. However, ECT is insensitive to heparins because heparins require antithrombin, which cannot react with meizothrombin or other intermediates of the prothrombinthrombin conversion with a thrombin activity [e.g. meizothrombin (desF1)] [5]. Prothrombinase-induced clotting time (PiCT) [6] is another novel testing technique based on clot activation by a toxin of a snake venom. RVV-Va from Russel's viper venom in the reagent activates factor $(\mathrm{F}) \mathrm{V}$ present in the test set-up. FVa forms the

\footnotetext{
J. Harenberg

Fourth Medical Department, University Hospital

Theodor-Kutzer-Ufer 1-3

D-68167 Mannheim (Germany)

Tel. +49 621383 3378, Fax +49621383 3808, E-Mail j-harenberg@t-online.de
}

E-Mail karger@karger.ch Accessible online at:

www.karger.com www.karger.com/pht 
prothrombinase complex with FXa (added in reagent), phospholipids and calcium ions. PiCT determines activities of direct and indirect thrombin inhibitors in a linear manner over a wide concentration range (up to 2,000 ng/ $\mathrm{ml}$ ) [6]. As PiCT is based on factors affected by oral anticoagulation (FX and FII), this test is presumably also sensitive to oral anticoagulants, just as aPTT and PT are [710], due to lower levels of these factors during therapy with vitamin $\mathrm{K}$ antagonists.

In the present study, we describe the effects of three direct thrombin inhibitors (hirudin, argatroban and melagatran) and of unfractionated heparin (UFH) on PiCT in normal plasma and in plasma of patients on steady-state oral anticoagulation with phenoprocoumon. Oral anticoagulation may be switched to direct thrombin inhibitors or heparins in special clinical settings like invasive diagnostics and surgery. During overlapping therapy, vitamin $\mathrm{K}$ antagonists as well as thrombin inhibitors are present and may have additive effects. The aim of the study was to determine the influence of oral anticoagulants on the monitoring of the aforementioned drugs and to investigate the utility of the method for monitoring UFH and direct thrombin inhibitors during oral anticoagulation.

\section{Materials and Methods}

Blood samples $(\sim 10 \mathrm{ml})$ of 4 healthy volunteers (normal plasma, $\mathrm{NP}$ ) and 6 patients (INR: $2.21 \pm 0.31$, mean \pm SD) on treatment (oral anticoagulant plasma, OACP) with the vitamin $\mathrm{K}$ antagonist phenoprocoumon (Hoffmann-La Roche, Basel, Switzerland) were collected by clean cubital vein puncture into plastic vials with sodium citrate (3.8\%; plasma/citrate: $9 / 1, \mathrm{~V} / \mathrm{V}$ ) and kaolin (coagulation time $30 \mathrm{~min})$. The centrifuged plasma samples $(1,800 \mathrm{~g}$ for $10 \mathrm{~min}$ ) were either tested immediately or shock frozen in liquid nitrogen and stored at $-80^{\circ} \mathrm{C}$ for analyses within 4 weeks. Plasma samples were spiked with concentrations ranging from 300 to $3,000 \mathrm{ng} / \mathrm{ml}$ of r-hirudin (Lepirudin ${ }^{\circledR}$, Aventis, Frankfurt/Main, Germany), argatroban (by courtesy of Mitsubishi Chemical Corp., Tokyo, Japan), and UFH (Liquemin ${ }^{\circledR}$, Hoffmann-La Roche) or melagatran ranging from 30 to $1,000 \mathrm{ng} / \mathrm{ml}$ (kindly provided by AstraZeneca, Mölndal, Sweden). In the case of heparin, 300 and $3,000 \mathrm{ng} / \mathrm{ml}$ corresponded to $0.048 \mathrm{IU} / \mathrm{ml}$ and $0.48 \mathrm{IU} / \mathrm{ml}$, based on a content of $160 \mathrm{IU} / \mathrm{mg}$ dry substance and an average molecular mass of $12.5 \mathrm{kD}$. All PiCT measurements were carried out in a KC 10a micro ${ }^{\circledR}$ device from Amelung Comp. (Lemgo, Germany) [11]. The prothrombinase reagent (test lot \#1) containing FV activator (RVV-FVa from Russel's viper venom), FXa and phospholipids was kindly provided by Pentapharm Ltd. (Basel, Switzerland). All data are given as mean values with standard deviations. For all calculations the mathematical and statistical functions of Microsoft Excel were used.

PiCT, Thrombin Inhibitors and

Phenprocoumon

\section{Results}

\section{PiCT Expressed in Seconds}

Normal PiCT range was $29.9 \pm 4.6$ in NP. In OACP, this value was prolonged to $36.3 \pm 20.3 \mathrm{~s}$. Lepirudin at $3,000 \mathrm{ng} / \mathrm{ml}$ delivered PiCT values of $128.0 \pm 23.4 \mathrm{~s}$ in $\mathrm{NP}$ and over $600 \mathrm{~s}$ in OACP (fig. 1a). The same amount of argatroban led to PiCT values of $151.0 \pm 23.9 \mathrm{~s}$ in NP and $233.7 \pm 57.2 \mathrm{~s}$ in OACP samples (fig. 1b). Maximum dose of melagatran $(1,000 \mathrm{ng} / \mathrm{ml})$ caused clotting times of $153.5 \pm 9.9 \mathrm{~s}$ in NP and $342.6 \pm 78.0 \mathrm{~s}$ in OACP (fig. 1c). By spiking with $3,000 \mathrm{ng} / \mathrm{ml}(0.48 \mathrm{IU} / \mathrm{ml}) \mathrm{UFH}, \mathrm{PiCT}$ prolongations to $137.0 \pm 8.4 \mathrm{~s}$ could be obtained with NP. In OACP, the presence of $3,000 \mathrm{ng} / \mathrm{ml}(0.48 \mathrm{IU} / \mathrm{ml})$ UFH prolonged aPTT to $186.8 \pm 42.2 \mathrm{~s}$ (fig. $1 \mathrm{~d}$ ). PiCT provided good linearity with UFH throughout the entire concentration range in NP as well as in OACP. Argatroban and melagatran also showed fairly good linearity in both groups for most of the concentration ranges tested. Lepirudin delivered a flat linear dose-response curve with $\mathrm{NP}$ up to $3,000 \mathrm{ng} / \mathrm{ml}$ and in OACP up to $2,000 \mathrm{ng} / \mathrm{ml}$.

\section{Individual Normalized PiCT Ratios}

The question emerged whether differences between NP and OACP samples could be substantially reduced or even abolished by formulating a ratio. With lepirudin, the maximal dose of 3,000 $\mathrm{ng} / \mathrm{ml}$ provided normalized PiCT values of $4.28 \pm 0.18$ in NP (fig. $2 \mathrm{a}$ ). In OACP, the same concentration delivered a ratio of 16.6 (SD not determined). With argatroban, the normalized ratio almost abolished the differences between both groups (fig. 2b). The maximum concentration tested $(3,000 \mathrm{ng} / \mathrm{ml})$ provided ratios of $5.0 \pm 0.16$ versus $6.44 \pm 0.2$ in NP and $\mathrm{OACP}$, respectively. With melagatran, PiCT ratios of $5.13 \pm 0.06$ versus $9.4 \pm 0.23$ were calculated when adding $1,000 \mathrm{ng} / \mathrm{ml}$ to NP and OACP, respectively (fig. 2c). A good equalising effect was also found with UFH, especially in higher concentration ranges (fig. 2d). Adding $3,000 \mathrm{ng} / \mathrm{ml}(0.48 \mathrm{IU} / \mathrm{ml}) \mathrm{UFH}$ delivered ratios around 5 in both groups $(4.58 \pm 0.06$ in NP versus $5.15 \pm 0.23$ in $\mathrm{OACP})$.

\section{Suggested Therapeutic Ranges for PiCT}

Based on the results presented here, therapeutic ranges can be suggested for direct thrombin inhibitors and UFH in normal plasma and during oral anticoagulation. PiCT has a more pronounced concentration-effect relationship with heparin and direct thrombin inhibitors than aPTT. With aPTT, the therapeutic range is a 1.5- to 3-fold prolongation of clotting times $[12,13]$. Therefore, a higher

Pathophysiol Haemost Thromb 2002;32:174-179 
Fig. 1. Concentration/activity-PiCT relationships of hirudin (a), argatroban (b), melagatran (c) and UFH (d) in normal plasma $(\mathrm{NP} ; \mathrm{n}=4)$ and plasma samples of patients on oral anticoagulation with phenprocoumon $(\mathrm{OACP} ; \mathrm{n}=6)$. Data are means $\pm \mathrm{SD}$.
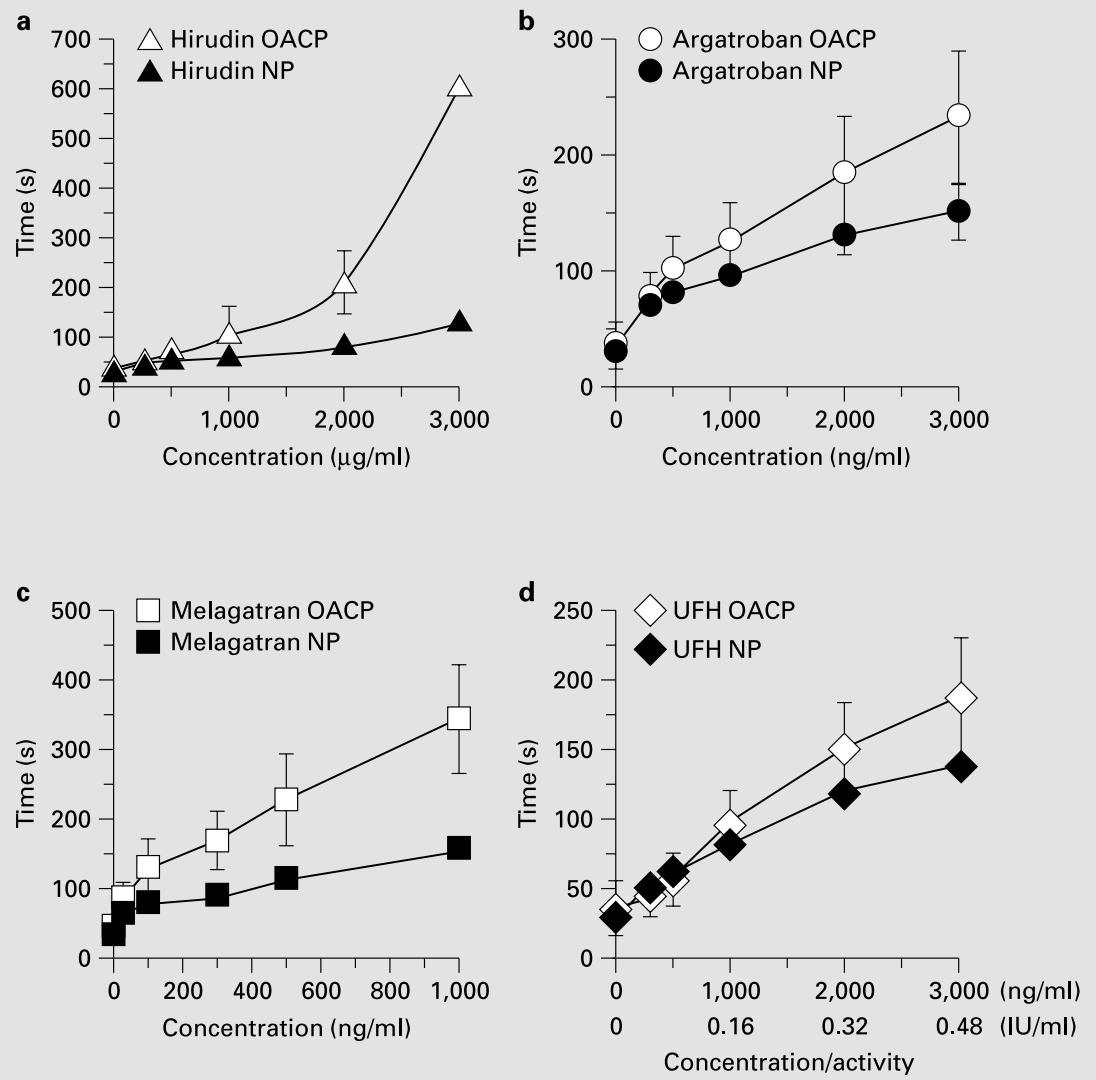

range of PiCT ratios, namely $2-3.5$, corresponds to concentration ranges which would also be achieved during therapy with UFH [12, aPTT monitoring], r-hirudin [14, 15, ECT monitoring] or argatroban [9, ECT monitoring]. Clinical data for PiCT monitoring are not available yet. Based on these ratios, the following therapeutic concentration ranges were calculated from the concentrationPiCT ratio relationships: between $600(0.096 \mathrm{IU} / \mathrm{ml})$ and $1,550 \mathrm{ng} / \mathrm{ml}(0.248 \mathrm{IU} / \mathrm{ml})$ for UFH in NP and OACP. With lepirudin, 1,000-2,600 $\mathrm{ng} / \mathrm{ml}$ were calculated for $\mathrm{NP}$ and $650-1,350 \mathrm{ng} / \mathrm{ml}$ for OACP. In the case of argatroban, therapeutic ranges of $225-1,200 \mathrm{ng} / \mathrm{ml}$ in NP and 225-1,000 ng/ml in OACP were found. Therapeutic concentration ranges for melagatran were $30-435 \mathrm{ng} / \mathrm{ml}$ in NP and 30-105 ng/ml in OACP.

Based on the normal PiCT range of $29.9 \pm 4.6 \mathrm{~s}$ in NP, the therapeutic range should be from $60 \mathrm{~s}(50-70 \mathrm{~s} ; 59.8$ \pm 9.2 ) to 105 (up to $120 \mathrm{~s} ; 104.7 \pm 16.1$ ).

\section{Discussion}

Differences of PiCT (in seconds) between NP samples and those on stable vitamin $\mathrm{K}$ antagonism therapy with phenprocoumon were found with all four drugs tested. By formulating individual normalized ratios, these differences could be abolished in the case of UFH and reduced in the case of argatroban and melagatran. With lepirudin, a weaker reduction effect was achieved, especially in higher concentration ranges.

The influence of oral anticoagulation on PiCT monitoring showed different patterns in the drugs tested. When testing UFH, interferences of linear additive appearance occurred only in medium and high concentration ranges (1,000-3,000 ng/ml). However, no interferences appeared below $1,000 \mathrm{ng} / \mathrm{ml}$. In the case of lepirudin, interferences between NP and OACP were potentiating with higher concentrations, but little effects occurred in the lower concentration range. This could possibly indicate a hyperad- 
Fig. 2. Concentration-normalized PiCT ratio relationships of hirudin (a), argatroban (b), melagatran (c) and UFH (d) in normal plasma (NP; $n=4)$ and plasma samples of patients on oral anticoagulation with phenprocoumon $(\mathrm{OA} ; \mathrm{n}=6)$. Data are means \pm SD.
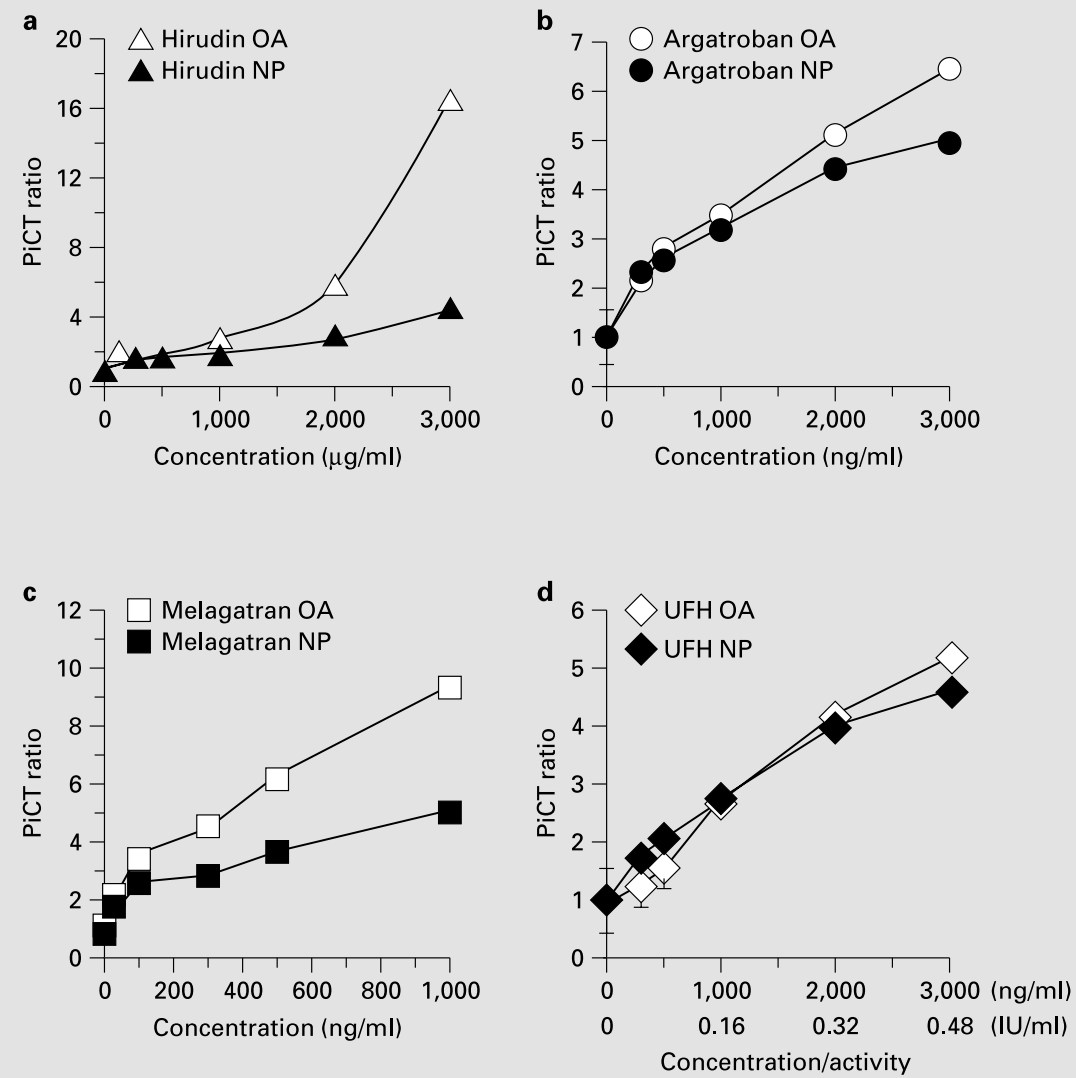

ditive effect in the presence of higher lepirudin concentrations. In contrast to lepirudin, the two other direct thrombin inhibitors, argatroban and melagatran, showed a linear additive influence on oral anticoagulation throughout the concentration range. No hyperadditive phenomenon occurred at the upper ends of the concentration-effect curves, in contrast to lepirudin.

The differing patterns of interactions with oral anticoagulant effects between UFH on the one hand and direct thrombin inhibitors on the other could possibly be explained by their differing modes of action. The tripeptidic inhibitors argatroban and melagatran act with a one-toone stoechiometry by monovalent binding to the catalytic active site of thrombin [16]. In the case of UFH and lepirudin, modes of action are more complex. UFH requires antithrombin as a cofactor for inhibition of thrombin, whereas lepirudin is a bivalent ligand for both the catalytic active site and the anion-binding exosite of thrombin $[17,18]$. In the case of lepirudin a more complex stoi- chiometry mediated by two binding sites leads to sigmoidal concentration-effect relationships. Besides different target sites, eventual affinity changes during oral anticoagulation due to higher relative inhibitor concentrations [19] might explain the diversity of interactions with oral anticoagulation of lepirudin versus argatroban and melagatran.

As a further possible mechanism, decreased carboxylation of coagulation factors II, VII, IX and X could alter the accessibility of the respective binding sites to different extents for each drug during therapy with vitamin $\mathrm{K}$ antagonists [20]. An eventual inhibition promiscuity for FII and FX described for some inhibitors [21] should also be taken into consideration as a possible reason. Feedback mechanisms between FII, FVII, FIX and FX could also play a role in generating the differences between the effects of oral anticoagulation on the actions of each direct thrombin inhibitor [22]. However, the precise mechanisms of these differences remain to be investigated. 
A practical implication of dose-response curve results for the therapeutic concentration ranges, based on a PiCT prolongation of 2.0-3.5 of the normal value. Due to more pronounced dose-PiCT ratio relationships in OACP, dosages are to be reduced in OACP. As the initial parts of the curves showed no significant differences between UFH, argatroban and melagatran, lower boundaries of therapeutic concentration ranges are identical in both groups, only the upper boundaries are different for NP and OACP. Lepirudin showed significant differences also at low therapeutic concentrations, leading to different boundaries of therapeutic concentration ranges for both groups.

The results of the present work indicate that the sensitivity of the method is suitably high for monitoring (unfractionated) heparins and direct thrombin inhibitors. The direct thrombin inhibitors hirudin and argatroban are established to maintain effective anticoagulation in patients with heparin-induced thrombocytopenia without (HIT type I) and with thrombosis (HITTS or HIT type II) [23-25]. Melagatran is currently under investigation in clinical studies [26-29].

Calatzis et al. [6] reported a normal PiCT range up to $30 \mathrm{~s}$. The normal PiCT range in the present study, $29.9 \pm$
$4.6 \mathrm{~s}$, agrees with their results. Their concentration-effect curves of hirudin (tested up to $2,500 \mathrm{ng} / \mathrm{ml}$ ) and UFH [tested up to $1 \mathrm{IU} / \mathrm{ml}(6,250 \mathrm{ng} / \mathrm{ml})$ ] were similar to those found in the present work. However, the dose-effect relationship of lepirudin is not as pronounced with $\mathrm{PiCT}$ as with ECT [30, 31].

According to our results and those described by Calatzis et al. [6], PiCT seems to be a suitable method for clinical practice in supervising dosages of heparins (UFH and LMWH [6]) and the direct thrombin inhibitors hirudin, argatroban and melagatran. The latter, however, do not need monitoring in clinical practice, according to the specifications of the manufacturer, because of the good predictability of drug levels proven in clinical trials [26, $28,32]$.

\section{Acknowledgements}

We would like to thank Mrs. Christina Giese, Mrs. Antje Hagedorn and Mrs. Inge Traeger for their excellent laboratory work and patient care. This study was supported by a grant of the Faculty of Clinical Medicine Mannheim, University of Heidelberg.

\section{References}

1 Van den Besselaar AM, Meeuwisse-Braun J, Bertina RM: Monitoring heparin therapy: Relationships between the activated partial thromboplastin time and heparin assays based on ex-vivo heparin samples. Thromb Haemost 1990;63:16-23.

2 Kher A, Gouin I, Samama MM: Followp-up of the treatment by direct thrombin inhibitors: Activated partial thromboplastin time or ecarin clotting time. Ann Biol Clin (Paris) 2000;58: 575-579 [in French].

3 Kitchen F, Preston FE: The therapeutic range for heparin therapy: Relationship between six activated partial thromboplastin time reagents and two heparin assays. Thromb Haemost 1996;75:734-739

4 Moser M, Ruef J, Peter K, Kohler B, Gulba DC, Paterna N, Nordt T, Kubler W, Bode C: Ecarin Clotting Time but not aPTT correlates with PEG-Hirudin plasma activity. J Thromb Thrombolysis 2001;12:165-169.

5 Schoen P, Lindhout T: The in situ inhibition of prothrombinase-formed human $\alpha$-thrombin and meizothrombin (desF1) by antithrombin III and heparin. J Biol Chem 1987;262:1126811274.
6 Calatzis A, Spannagl M, Gempeler-Messina P, Kolde HJ, Schramm W, Haas S: The Prothrombinase-induced Clotting Time, a new technique for the monitoring of anticoagulants. Haemostasis 2000;30(suppl 2):172-174.

7 Hursting MJ, Zehnder JL, Joffrion JL, Becker J-C, Knappenberger GD, Schwarz RP: The international normalized ratio during concurrent warfarin and argatroban anticoagulation: Differential contributions of each agent and the effects of the choice of thromboplastin used. Clin Chem 1999;45:409-412.

8 Sheth SB, DiCicco RA, Hursting MJ, Montague $\mathrm{T}$, Jorkasky DK: Interpreting the international normalized ratio (INR) in individuals receiving argatroban and warfarin. Thromb Haemost 2001;85:435-440.

9 Walenga JM, Fasanella AR, Iqbal O, Hoppenstaedt D, Sarfraz A, Wallis D, Bakhos M: Coagulation laboratory testing in patients treated with argatroban. Semin Thromb Hemost 1999; 25(suppl 1):61-66.

10 Faaij RA, van Griensven JMT, Schoemaker RC, Goggin T, Guenzi A, Kroon JM, Burggraaf J, Cohen AF: The effect of warfarin on the pharmacokinetics and pharmacodynamics of napsagatran. Eur J Clin Pharm 2001;57:2529.
11 Thomson JM, Taberner DA, Poller L: Automation and prothrombin time: A United Kingdom field study of two widely used coagulometers. J Clin Pathol 1990;43:679-684.

12 Hirsh J, Warkentin TE, Shaughnessy SG, Anand SS, Halperin JL, Raschke R, Granger C, Ohman EM, Dalen JE: Heparin and low-molecular-weight heparin - Mechanisms of action, pharmacokinetics, dosing, monitoring, efficacy and safety. Chest 2001(suppl 1);119:64-94.

13 Basu D, Gallus A, Hirsh J, Cade JF: A prospective study of the value of monitoring heparin treatment with the activated partial thromboplastin time. N Engl J Med 1972;287:324327.

14 Poetzsch B, Hund S, Madlener K, Unkrig C, Mueller-Berghaus G: Monitoring of recombinant hirudin: Assessment of a plasma-based ecarin clotting time assay. Thromb Res 1997; 86:373-383.

15 Lindhoff-Last E, Piechottka GP, Rabe F, Bauersachs R: Hirudin determination in plasma can be strongly influenced by the prothrombin level. Thromb Res 2000;100:55-60.

16 Nilsson T, Sjoling-Ericksson A, Deinum J: The mechanism of binding of low-molecular-weight active site inhibitors to human $\alpha$-thrombin. J Enzyme Inhib 1998;13:11-29. 
17 Fenton JW, Villanueva GB, Ofosu FA, Maraganore JM: Thrombin inhibition by hirudin: How hirudin inhibits thrombin. Haemostasis 1991;21(suppl 1):27-31.

18 Maraganore JM, Bourdon P, Jablonski J, Ramachandran KL, Fenton JW: Design and characterization of hirulogs: A novel class of bivalent peptide inhibitors of thrombin. Biochemistry 1990;29:7095-7101.

19 Elg M, Gustafsson D, Deinum J: The importance of enzyme inhibition kinetics for the effect of thrombin inhibitors in a rat model of arterial thrombosis. Thromb Haemost 1997; 78:1286-1292.

20 Johnson BC: Post-translational carboxylation of preprothrombin. Mol Cell Biochem 1981; 38:77-121.

21 Nar H, Bauer M, Schmid A, et al: Structura basis for inhibition promiscuity of dual specific thrombin and Factor Xa blood coagulation inhibitors. Structure (Camb) 2001;9:29-38.

22 Baumann P, Heuck CC: Simulation of the extrinsic pathway of the plasmatic clotting system. Haemostasis 1991;21:329-337.

23 Greinacher A, Völpel H, Janssens U, HachWunderle V, Kemkes-Matthes B, Eichler P, Mueller-Velten HG, Poetzsch B, for the HIT Investigators Group: Recombinant hirudin (Lepirudin) provides safe and effective anticoagulation in patients with heparin-induced thrombocytopenia. A prospective study. Circulation 1999;99:73-80.
24 Harenberg J, Huhle G, Piazolo L, Wang LU, Heene DL: Anticoagulation in patients with heparin-induced thrombocytopenia type II. Semin Thromb Hemost 1997;23:189-196.

25 Lewis BE, Wallis DE, Berkowitz SD, Matthai WH, Fareed J, Walenga JM, Bartholomew J, Sham R, Lerner RG, Zeigler ZR, Rustagi PK, Jang IK, Rifkin SD, Moran J, Hursting MJ, Kelton JG: Argatroban anticoagulant therapy in patients with heparin-induced thrombocytopenia. Circulation 2001;103:1838-1843.

26 Eriksson UG, Frison L, Gustafsson D, Mandema J, Karlsson MO, Waehlby U, Eriksson BI: Effect of melagatran, the active form of the oral direct thrombin inhibitor, ximelagatran (pINN, formerly H 376/95), on activated partial thromboplastin time in orthopaedic surgery patients treated to prevent deep vein thrombosis and pulmonary embolism (abstract P 3093). Thromb Haemost Suppl 2001;86 (CD ROM).

27 Eriksson BI, Ögren M, Agnelli G, Cohen A, Dahl OE, Mouret P, Rosencher N, Eskilson C, Nylander I, Frison L: The oral direct thrombin inhibitor ximelagatran (pINN, formerly H 376/ 95) and its subcutaneous form melagatran compared with enoxaparin as thromboprophylaxis after total hip or total knee replacement (abstract OC 1638). Thromb Haemost Suppl 2001;86 (CD ROM).
28 Eriksson H, Wahlander K, Gustafsson D, Welin L, Schulman S: Efficacy and tolerability of the novel, oral direct thrombin inhibitor, ximelagatran (pINN, formerly H 376/95), compared with standard therapy for the treatment of acute deep vein thrombosis (abstract OC 2348). Thromb Haemost Suppl 2001;86 (CD ROM).

29 Francis CW, Davidson BL, Berkowitz, Lotke PA, Ginsberg JS, Liebermann JR, Webster AK, Whipple JP, Colwell CW: Randomised, double-blind, comparative study of ximelagatran (pINN, formerly $\mathrm{H} 376 / 95$ ), an oral direct thrombin inhibitor, and warfarin to prevent venous thromboembolism (VTE) after total knee arthroplasty (TKA) (abstract OC 44). Thromb Haemost Suppl 2001;86 (CD ROM).

30 Nowak G, Bucha E: Quantitative determination of hirudin in blood and body fluids. Semin Thromb Hemost 1996;22:197-202.

31 Nowak G: Clinical monitoring of hirudin and direct thrombin inhibitors. Semin Thromb Hemost 2001;27:537-541.

32 Eriksson UG, Frison L, Gustafsson D, Mandema J, Karlsson MO, Eriksson BI: The pharmacokinetics of melagatran, the active form of the oral direct thrombin inhibitor ximelagatran (pINN, formerly H 376/95) in orthopaedic surgery patients treated to prevent deep vein thrombosis and pulmonary embolism (abstract P 3092). Thromb Haemost Suppl 2001;86 (CD ROM). 